\title{
Execution of the Public Procurement Procedure
}

\author{
Eduard Armeanu \\ PhD. Candidate, Academy of Economic Studies from Bucharest \\ Pta. Romana, Nr. 6, Sector 1, Bucharest, Romania \\ E-mail: armeanu@gmail.com
}

Received: June 10, 2011

Accepted: July 20, $2011 \quad$ Published: November 1, 2011

doi:10.5539/ijbm.v6n11p181

URL: http://dx.doi.org/10.5539/ijbm.v6n11p181

\begin{abstract}
The development of a company is closely connected with its economical development and the economical growth of a company cannot be possible without a properly developed public system. In return, it cannot exist without an efficient procurement process. Below we are going to briefly present which are the main stages of the public procurement procedure according to the legislation in force in order to emphasize the strengths and the weakness of the process, to highlight possible activities that can generate delays in the process etc.

Keywords: Public procurements, Execution, Stages, Documentation

\section{Introduction}

A transparent public administration implies the development of skills for conducting projects/ investments in the interest of the community. Of all government activities, public procurement are the activities most vulnerable to corruption, having a fundamental role in the economic development of states (according to specialists, public procurement represents about $16 \%$ of the GDP of the European Union). According to the above mentioned legislative provisions, the public procurement system is the instrument based on which public spending is done in the interest of the community, in which the demand of a public institution meets the supply of an economic agent (public or private).

The public procurement process aims at creating the framework required for conducting the procurement or investment process in the field of public services (Băşanu \& Pârjol, 1998); at the same time, this process ensures the disbursement of the funds distributed to the contracting authorities/ public institutions. These must manage such funds so that, throughout the year, they might properly conduct their activity. The public procurement process is a sequence of stages and, after going through them, the product, service or work is obtained as a result of the awarding of the public procurement contract.
\end{abstract}

\section{Main stages of the procurement procedure}

After elaborating the procurement plan, the execution of the procurement procedure is initiated. The main stages that need to be run through are the following:

\subsection{Notice of intent}

The notice of intent is obligatorily submmited for publication when one is trying to benefit from the reduced deadlines and implicitly from the duration of the execution of the process. If the contracting authority does not want to reduce the deadlines, then the publication of the notice of intent is optional. For the products and services agreements, the notice of intent is submmited for publication as soon as possible after the fiscal year starts. For the works agreements or the framework agreement, the notice of intent is submmited for publication as soon as possible after the approval of the public procurement plan where the respective works agreement or framework agreement is provided.

A summarized situation of the notice of intent (in terms of necessity of publication, location of publication, content, etc.) is presented in the table no. 1.

\subsection{Awarding method}

The awarding methods of the public procurement agreement are traditional methods (open tendering, restricted tendering, competitive dialog, negociation with a previous participation notice, negociation without a previous participation notice, call for tenders, solution bid, direct procurement) and special methods (framework agreement, the dynamic procurement system, electronic tendering).

In terms of the applicability for each individual type of awarding, the situation is presented in the table no. 2 .

\subsection{The elaboration of the awarding documentation}

The awarding documentation is the documentation that contains all the requirements, rules, information regading the object of the agreement and its awarding procedure, including the tender book or, where appropriate, the descriptive documentation. The awarding documentation contains the formal, technical and financial requirements which allow the objective description of the object of the agreement and based on which the financial officer will elaborate his tender (Swaminathan, 1998). The responsability for the elaboration of the awarding documentation 
belongs to the internal department of the contracting authority, specialized in awarding the public procurement agreements.

The structure of the awarding documentation must contain: the procurement data sheet; the tender book, or, where appropiate, the descriptive documentation; the proposal agreement; forms and examples. The awarding documentation should not contain conflicting information and information that contravene the stipulations in the participation notice.

The main element of the awarding documentation is the tender book or the descriptive documentation (Goyal \& Giri, 2001). The tender book is elaborated by the contracting authority for the open tendering, resctricted tendering, call for tender, by the instrumentality of the specialized internal department or of specialist (consultants) employed to that effect, in compliance with the legal provisions regarding the competition and conflict of interests. The tender book represents the objective description of products, services or works required by the contracting authority.

The descriptive documentation stands for the tender book for cases where application of negociation procedures and competitive dialog is appropiate. The term "descriptive" was chosen to indicate that this documentation is less detailed than the tender book, which consists in indications regarding the performances that can be obtained, the legal, administrative and contractual requirements which will form the basis for the performance of the procedure and for the preparation of the tenders. The descriptive documentation contains a description of the requirements, objectives and constraints of the contracting authority; any other information based on which is conducted the dialog for identifying the viable solutions.

\subsection{Call for competition}

In order to ensure the transparancy of the awarding of the public procurement agreements, the contracting authority, whenever wishes to award a public procurement agreement or to conclude a framework agreement, has the obligation to publish a tender notice or an invitation to tender, according to the procedure being applied (table no. 3).

For the application of the procedures for restricted tendering, competitive dialog or negociation with publication of a notice, the notice of tender for the candidats selection / preselection stage, must contain: selection/preselection criteria; applicable rules; minimum number of applicants to be selected or preselected; maximum number of applicants to be selected or preselected; dealine and location for applications submission.

The invitation to tender must be submitted when: a) is initiated the procedure for call for tender for awarding the public procurement agreement/for the conclusion of the framework agreement; $b$ ) takes place a negociation without the publication of a notice for tender; c) is desired the awarding of a subsequent agreement (table no. 4).

If, for technical reasons, the ESPP officer is unable to submitt a certain notice for publication in the Official Journal of the European Union, he has the obligation to inform the contracting authority no latter than one working day since the appearance of the situation, the latter having the responsability to submitt for publication the respective notice by its own means (Nicolescu et. al., 2006).

\subsection{Presentation of the application and tender}

Application means the documents by means of which the applicant demonstrates his personal situation, his competency to conduct his professional activity, his economical and financial situation as well as his technical and professional competency. The application is required in order to obtain the invitation to tender for the subsequent submission of the tender, for cases where a restricted tendering, negociation, competitive dialog procedure is applied.

The tender represents the document by means of which the financial officer expresses his willingness to legally commit in a public procurement agreement. Any tender can be amended before the deadline for the submission of tenders. The definitive elements of the tender are the financial proposal, the technical proposal and the qualification documentation. The tender is elaborated in accordance with the provisions in the awarding documentation and must be complete, decisive, real and serious. A variation of the tender is represented by the alternative tender, the tender that can deflect to a certain extent from the tender book requirements. This can be submmited along with the main tender only in cases where the awarding criterion is "the most economically advantageous tender" and only if the contracting authority allowed this by instrumentality of notice of tender (Fundătură et. al., 1992). The alternative tender must meet, in terms of quality solutions and requirements, the minimum requirements provided in the tender book. The alternative tenders can deflect from the provisions of the tender book if they meet the minimum provided requirements and if they offer more favorable conditions for the contracting authority.

In respect of the presentation of the tender and application, they are submitted in orginal and in a number of copies, if this was required by the Procurement data sheet. Copies of applications/tender are necessary for the committee members for the evaluation process. In the event of a discrepancy between the original and the copies, the original prevails.

For the documents issued by official institutions/bodies empowered to that effect, the respective documents must be signed and sealed according to the legal provisions. Any deletion, addition, interlining or superposed writing is valid only if they are approved by the person/persons authorized to sign the tender. 
The tenderer must seal the original and every set of copies in separate envelopes, duly marking the envelopes with "ORIGINAL" and respectively "COPY". The envelopes are introduced in an exterior envelope, duly sealed and light-tight. The interior envelopes must be marked with the name and address of the tenderer in order to allow the tender to be returned without being opened, if the respective tender is declared overdue. The technical and financial proposal and, where appropiate, the qualification documents and the alternative tenders will be introduced as provided in the Procurement data sheet, in separate envelopes, duly marked.

\subsection{The awarding procedure itself}

The applications selection is performed by applying selection criteria. The applicants are selected by using objective and non discriminatory criteria relating only to the technical and economical and financial competency. The tenderer has the right to submitt the tender by mail or directly at the specified address.

Together with the initiation of the application of the procedure for awarding the public procurement agreement, the contracting authority will establish an evalution committee. The evaluation committee is composed of at least 3 members, independent from the procedure applicants, which can be permanent employees of the contracting authority. The President of the evaluation committee is the person responsable for awarding the agreement. The person responsable for awarding the agreement can suggest the co-optation of experts from other departments of the authority or of other external experts who will carry on their activity alongside the evaluation committee members. The number of the committee members must be uneven. The contracting authority is entitled to replace an evaluation committee member with a spare member only if the person to be replaced is unable, for objective reasons, to perform his specific duties arising from his membership to the evaluation committee. Following the replacement procedure, the membership to the evaluation committee is taken by the spare member who assumes the activity starting with the moment of replacement and until the conclusion of the procedure applied for awarding the respective public procurement agreement (Arnold \& Stephen, 2003).

Throughout the application of the awarding procedure, all necessary measures must be taken in order to avoid certain situations meant to determine the existence of a conflict of interests and/or a situation which will allow the representation of the unfair competition. Should this situation arise the contracting authority has the obligation to eliminate the effects arising from such an event, by taking, according to its competencies, remedies like: change, termination, revocation, annulment of the documents which affected the correct application of the awarding procedure or of the activities relating to it. By conflict of interests it is understood the situation where the public employee has a personal interest that might inappropriately influence the fullfilment of his work related duties and obligations (Pricop \& Draghici, 1999). The conflict of interests appears when the employees or the officials in the public sector are influenced or appear to be influenced by personal interests when performing their activity.

Tenders open on - hour/day/month/year - and location indicated in the notice/invitation for tender and in the awarding documentation only after verifying the existence of the tender guarantee in cuantum of and having the requested validity period. Any tenderer is entitled to attend the tenders opening meeting (McGovern, Hicks \& Earl, 2005). Within the tenders opening meeting, the evaluation committee verifies the compliance with the formal aspects of submission and presentation of the tenders and accompanying documentation. The tenders will be opened by the President of the evaluation committee who has the obligation to announce the following information: designation (name) of the tenderers; tender amendments and withdrawals; the existence of the tender guarantees; the main elements of the financial proposals, including the price; the reference rate that will be the basis of comparing the prices on the evaluation of the tenders submitted in another curency; proposals for alternative tenders (where appropiate); any other details and specifications which the evaluation committee deems to be necessary. Any decision regarding the qualification of the tenderers, respectively the applicants, or, where appropiate, regarding the evaluation of the tenders, will be made by the evaluation committee within a series of meetings subsequent to the tenders opening meeting. The evaluation committee will draw up an opening minutes that must include the information announced by the President of the committee.

The mode of action of the evaluation committee is established by the President of the committee in mutual agreement with its members. The person responsable for the awarding of the agreement is the President of the committee. In evaluating the tenders, the committee will keep into consideration the estimative timetable for the application of the procedure and the period requested for the tenders validity. Only the committee members have a vote. Any decision of the evaluation committee must meet the vote of at least $2 / 3$ of its number of members. If the winning tender is established based on a synopsis, the vote of the evaluation committee members is reflected by individual synopsis given for each individual tender. If there are differences in opinions between the evaluation committee members and the decision does not meet the vote of $2 / 3$ of its members number, then the President of the committee will request the reconsideration of the difference synopsis, in order to complete in due time the tenders evaluation stage stand to establish the winning tender. If the evaluation committee fails to reach an agreement, the final decision is adopted by simple majority.

The evaluation committee has the obligation to perform the examination and evaluation activities only at the contracting authority's headquarters (Taylor \& Smidt, 1970). The evaluation committee has the obligation to establish the winning tender between the admissible tenders, based on applying the criterion for awarding the public procurement agreement. If the criterion used was "the most economically advantageous tender", then the tenders' evaluation is performed by granting, for each individual tender, a synopsis as a result of applying the calculation algorithm established in the awarding documentation. If the criterion used was "exclusively the lowest price", then the tenders evaluation is performed by comparing the price, without VAT, for each individual tender 
and by drawing up, in descending order of the respective prices, the classification based on which the winning tender is established. If the criterion applied for awarding the public procurement agreement is "the most economically advantageous tender", and the evaluation committee granted the same synopsis for two or more tenders, then the contracting authority has the obligation to conclude the agreement with the tenderer whose tender has the lowest price. If the tendered prices are also equal, then the contracting authority is entitled to:

- $\quad$ either solicit the tenderers who offered the lowest price a new financial proposal in a sealed envelope, in which case the agreement will be awarded to the tenderer whose new financial proposal has the lowest price;

- or to award the public procurement agreement to one of the tenderers who have offered the lowest price, based on applying some additional criteria exclusively technical;

- If the criterion applied for awarding the public procurement agreement is "exclusively the lowest price", and two or more tenders contain, within the financial proposal, the same price, the contracting authority is entitled to:

- $\quad$ either solicit the tenderers who offered the lowest price a new financial proposal in a sealed envelope, in which case the agreement will be awarded to the tenderer whose new financial proposal has the lowest price;

- $\quad$ or to award the public procurement agreement to one of the tenderers who have offered the lowest price, based on applying some additional criteria exclusively technical;

\subsection{The awarding of the public procurement agreement}

The contracting authority has the obligation to inform the financial officers participating at the procedure regarding decisions relating to: the awarding of the public procurement agreement; the conclusion of the framework agreements; the admission in a dynamic procurement system; the decision regarding the annulment of the awarding procedure (Arcelus et. al., 2002).

The winning financial officer or the winning financial officers ask about accepting the submitted tender/tenders/solution/solutions. The financial officers participating at the procedure who have been rejected or whose tender was not declared winner, ask about the reasons behind the respective decision, as follows:

- $\quad$ for each rejected applicant/competitor, the actual reasons behind the decision for rejecting his application;

- $\quad$ for each rejected tender, the actual reasons behind the decision of rejection;

- $\quad$ for each losing financial officer, the deadline until they are entitled to submitt an appeal, without affecting the minimum deadlines provided by the GEO 34 / 2006.

\subsection{Signing the agreement}

The awarding procedure of the agreement is completed by signing the agreement.

The provisions contained in the tender regarding the technical and financial proposals, the agreement performance chart, the payments chart, the bank guarantee execution, where appropiate, become an integral part of the agreement to the extent that they do not affect the mandatory provisions. If parts of the public procurement agreement are to be performed by one or more subcontractors, then the contracting authority must solicit upon the conclusion of the agreement, the submission of agreements concluded between the future contractor and the designated subcontractors.

\subsection{Completition of the awarding procedure}

The completition of the awarding procedure is achieved by submitting for publication, the notice of awarding and by completing the public procurement file (Nicolescu \& Verboncu, 2006). The notice of awarding is published no latter than 48 days after the completition of the awarding procedure. For the awarding of the media publicity agreements, with an annual cummulated value, without VAT, estimated greater than the equivalent in LEI of 2000 EUROS, the contracting authority has the obligation to publish a notice of awarding in the public utility information system available on the Internet at a dedicated address and on its own Internet page, where appropiate. A summarized situation regarding the notice of awarding is presented in the table no. 5.

After the publication of the notice of awarding, it's initiated the procedure of elaborating the public procurement file which contains all activities performed within a awarding prcedure, respectively all documents necessary for the performance of the procedure. The public procurement file is elaborated and kept by the contracting authority by instrumentality of the internal department specialized in public procurements (Cârstea, 1995). The file is elaborated for each awarded public procurement agreement, each concluded framework agreement or each awarded concession agreement. The public procurement file can be made available to:

- $\quad$ any relevant public authority for consultation, provided that no information is disclosed if its disclosure would be against the law, if it would impede law enforcement, it would affect the public interest, it would prejudice the legitimate commercial interest of the Parties or it would affect the free competition;

- the competent authorities to receive documents which may serve to prove frauds, contraventions or crimes.

If the original public procurement agreement is required, the contracting authority makes a copy of it. The public procurement file is made available to the interested Parties, based on a delivery receipt report which should include the list of contained documents as well as the number of pages of each document. The public procurement file is a public document. 


\subsection{The agreement performance guarantee}

The agreement performance guarantee ensures the contracting authority on the quantitative, qualitative and within the agreed period performance of the agreement. The agreement performance guarantee can be built in several forms. The contracting authority is entitled not to require the tenderers to form the performance guarantee:

- $\quad$ in case of a delivery or a services agreement, except the design services, whose estimated value is less than the amount of 75.000 EUROS;

- in case of the agreement awarded as a result of applying the negociation procedure without previously publishing a notice of tender.

The performance guarantee shall be constituted in the period preceding the signing of the agreement (if the guarantee is constituted by letter of performance guarantee or by ammounts deposited at the money office, if the value is small) or subsequent to its signing (if the performance guarantee is constituted by consecutive deductions from the intermediate payment balances), within a deadeline agreed by the Parties in writing and entered in the agreement. The date of the performance guarantee is the date on which the public procurement agreement becomes effective.

The performance guarantee quantum will not exceed $10 \%$ from the agreement price, excluding VAT. For the tenderes who are found in the SMSE-es category (presenting in this respect the documentation provided in the Law no. 346/2004, including subsequent amendments and additions), the performance guarantee is constitued in a 50\% rate from the quantum provided in the awarding documentation. In respect of the validy of the performance guarantee, it is normally equal to the duration of the agreement. In terms of constitution, the performance guarantee is constituted by one of the following forms: a) performance bond issued by the bank institutions, by other competent institutions or other insurance companies(Note 1); b) by depositing at the money office an ammount for the performance bonds with reduced value; c) by consecutive deductions from the ammounts due to partial invoices (only with the Parties consent).

The performance bond is issued according to the contract provisions and if there are no demands made over it. In terms of retaining the performance bond, the contracting authority is entitled to make demands over it, within the limit of the prejudice caused, if the contractor does not fulfill his obligations under the agreement, with the obligation to notify the demand, setting out the obligations which were not complied with (Lewis \& England, 1993).

\subsection{Execution of the agreement}

The agreement which is the object of the awarding procedure becomes effective either subsequent to the constitution of the performance bond, if it was requested, either at the deadline agreed by the Parties.

The execution of the agreement must be performed so as the Parties fulfill their obligations in good faith, both quantitatively and qualitatively, at the deadline established in the contract (Delaney et al.). Throughout the execution of the agreement, various activities can be undertaken: announcing the contractor on the startup of the activity; monitoring the contained activities for compliance with stipulations in the agreement (verifying the quality standards, the quantities, the objectives and the established period); documentation for the acceptance of deliveries; monitoring the expenditure, ensuring the availability of funds; verifying the accuracy of invoices and approving the invoices for payments; verifying the amendments requests and/or the agreement renewal in time; verifying if all activities are completed and accepted by the direct beneficiaries before the agreement's expiry date; announcing the specialized department in case of disputes/litigations; performing termination of the agreement; performing an updated audit report on the agreement administration.

If the agreement is concluded between more financial officers, and the subsequent agreements are to be awarded by reopening the competition, then the contracting authority has the obligation, whenever it decides the procurement of the products/services/works which make the object of that respective agreement, to simultaneously submitt an invitation for a new tender to all the financial officers subscribers of the agreement (Gross, 2010).

\subsection{Completition of the agreement}

The partial and/or final reception means the operation whereby the contracting authority expresses its consent on the products, services and works resulted from a public procurement agreement and based on which the payment is performed. Usually, after the final reception, the last payment or the final release of the agreement performance bond are performed. Reception is performed by a reception committee. The reception committee has the obligation to determine the stage and fulfilment of the obligations under the agreement (Băşanu \& Pricop, 2001).

For the reception of works agreements, the contractor shall ensure that on the reception date, the performed work will present the qualities declared by him in the agreement, will comply with the technical regulations in force and will not be affected by flaws which would decrease or cancel its value of usability according to the normal conditions os use or to those specified in the agreement. On the completion of the works the contractor has the obligation to notify in writing the purchaser that the reception conditions are complied with, requesting him to call out the reception committee. Based on the statuses of the works performed and confirmed and based on the findings performed on the field, the purchaser will appreciate if the conditions for calling out the reception committee are met. If faults or deficiencies are found, they will be notified to the contractor, establishing the deadlines for reparation and completion. After ascertaining the reparation of all faults and deficiencies, on a new request from the contractor, the purchaser will call out the reception committee. 
For the reception of services agreements the purchaser is entitled to verify the way the services were performed in order to establish compliance with the provisions in the technical proposal and in the tender book. Verifications will be performed in compliance with the provisions in the agreement. The purchaser has the obligation to notify in writing the contractor, the identity of his representatives authorized for this purpose.

For the reception of delivery agreements the purchaser or his representative is entitled to inspect and/or to test the products in order to verify their compliance with the specifications in the annex/annexes to the agreement. If one of the inspected or tested products does not comply with the specifications, the purchaser is entitled to reject it, and the supplier has the obligation, without modifying the price of the agreement, to: replace the rejected products or to undertake all the necessary modifications for the products to comply with their technical specifications.

\section{Conclusions}

Finally, the ascertaining document regarding the fulfillment of the contract obligation is issued. The contracting authority has the obligation to issue the contractor ascertaining documents that contain information regarding the fulfillment of the contract obligations and the possible prejudices incurred throughout the execution of the agreement.

After choosing the procurement procedure, the necessary funds shall be identified to represent the operation aiming to ensure the funding required for performing the contract. In practice, the following funding sources are available: the state budget, the local budget, EU funds, funds obtained from international financial institutions, bank loans, grants, and other sources.

There is no doubt that the provision of resources (financial, material, human) is a process of fundamental importance for ensuring the improvement of efficiency in any organization. Unlike the private sector (in which this activity takes place almost exclusively based on economic criteria and requirements), for the public administration (component of the public sphere) should be considered additionally both social criteria and transparency requirements (based on the fact that the public sector involves significant financial resources from public sources: state budget, local budgets, national public funds etc.). In the presented paper we illustrated the main aspects of public procurement in Romania, to identify opportunities to improve the economic efficiency of the organization. It is known that any delay in the resource's supply process (through the public procurement) can lead to major deficiencies in the activities of an institution (eg. challenging the acquisition proceedings may result in cancellation of the procurement process already carried out and, in this way, delays can occur in the resource's supply process). Therefore, detailed description of steps that compose the procurement process is useful and can be an interesting guide for experts.

\section{References}

Arcelus, F.J., Shah, N.H., \& Srinivasan, G. (2002). Retailer's pricing, credit and inventory policies for deteriorating items in response to temporary price/credit incentives. International Journal of Production Economics, 81(2), 153-162. http://dx.doi.org/10.1016/S0925-5273(02)00269-4

Arnold, J. R. Tony \& Stephen N. C. (2003). Introduction to Materials Management, fifth edition. Upper Saddle River, NJ: Prentice Hall, pg. 123 - 125, ISBN 978-0131128743.

Băşanu, G., \& Pârjol, M. (1998). Organizarea rațională a activitaților de depozitare a resurselor materiale şi de recuperare a celor reutilizabile (Rational Structure of Activities for Storing the Material Resources and for Recovering the Reusable Materials), Reference office for the technical and material supply, OID - MAGF, Bucharest, pg. 15-18.

Băşanu, G., \& Pricop, M. (2001). Managementul aprovizionării şi desfacerii (Supply and Sale Management), Editura Economică Publishing House, Bucharest, pg. 102-109.

Cârstea, G. (1995). Managementul resurselor material. Editura Gall, Bucharest, pg. 75-79.

Delaney P. R., James R. Adler, Epstein B., and Michael F. Foran. (1998). GAAP 98: Interpretation and Application of Generally Accepted Accounting Pricinples 1998. New York, NY: John Wiley \& Sons, Inc., pg. 117-125.

Fundătură, D., Băşanu, G., Pricop, M., \& Popescu D. (1992), Dicționar de management -aprovizionare, depozitare, desfacere, Editura S.C. Diacon Coresi” S.R.L., Bucureşti, pg. 59-65.

Goyal, S.K., \& Giri, B.C. (2001). Recent trends in modeling of deteriorating inventory. European Journal of Operational Research, 134, pg. 1-16. http://dx.doi.org/10.1016/S0377-2217(00)00248-4

Gross M. (2010). Optimisation of procurement processes by the example Sanitärtechnik Eisenberg, Prifysgol Cymru University of Wales, ISBN 978-3-640-81704-7. http://dx.doi.org/10.3239/9783640817047, pg. 20

Lewis, H.T., \& England, W.B. (1993). La fonction d'approvisionnement dans l'entreprise (Role of Supply within the Company), Dunod Publishing House, Paris, pg. 39-45.

Nicolescu, O., \& Verboncu I. (2006). Management comparat (Compared Management). Editura Economică Publishing House, Bucharest, pg. 95-107.

Nicolescu, O., Plumb I., Pricop I., \& Vasilescu I. (2006). Abordări moderne în managementul şi economia organizației, vol. 4, Editura Economică, Bucureşti, pg. 135-137, ISBN 973-590-86-11.

Pricop, M., \& Draghici, C. (1999). Sisteme moderne în managementul aprovizionării (Modern systems in the Supply Management), Tribuna Economică Publishing House, ISBN 973-934-82-89, pg. 54-57. 
Swaminathan, Jayashankar M., Smith, Stephen F., \& Sadeh, Norman M. (1998). Modeling Supply Chain Dynamics: A Multiagent Approach, In: Decision Sciences 29/1998, p. 607-632. http://dx.doi.org/10.1111/j.1540-5915.1998.tb01356.x

T. McGovern, C. Hicks, C.F. Earl. (2005). A review of supply chain management issues in engineer to order supply, Proceedings of the Seventh International Annual IPSERA, pg. 25-29.

Taylor, R.E., \& Smidt, J.W. (1970). Simulation and Analysis of Industrial System. Richard D. Irwin Publushing House, Bucharest, pg. 39-42.

Notes

Note 1. Ordinance no. 28 from 26/01/2006 regarding the settlement of financial and fiscale actions, published in the Official Gazette, Part I no. 89 from 31/01/2006 and Law no. 136 from 29/12/1995 regarding the insurances and reinsurances in Romania, including the subsequent amendments and additions, published in the Official Gazette, Part I no. 303 from 30/12/1995

Note 2. SEAP - Electronic System of Public Procurement

Table 1.

\begin{tabular}{|l|l|l|l|}
\hline \multicolumn{1}{|c|}{ Why publish the notice of intent } & When is it published & \multicolumn{1}{|c|}{ Where is it published } & \multicolumn{1}{|c|}{ What it contains } \\
\hline $\begin{array}{l}\text { For reducing the deadlines for } \\
\text { drawing up the tenders and only if }\end{array}$ & $\begin{array}{l}\text { As soon as possible } \\
\text { after the fiscal year }\end{array}$ & $\begin{array}{l}- \text { in the Official Journal of } \\
\text { the EU, through ESPP }\end{array}$ & $\begin{array}{l}\text { Information } \\
\text { provided in the (EC) }\end{array}$ \\
the total estimated value for the next & starts & (Electronic System for & Regulation No. \\
12 months of the agreements that & or as soon as possible & Public Procurement) and & 1564/2005 for: \\
will be awarded or of the framework & after the approval of & in ESPP(Note 2) & Annex I - Standard \\
agreements that will be concluded is & the programme where & - only in ESPP if there is a & Form 1: ,Notice of \\
greater than or equal to: & the works agreement & simplified notice of & intent” \\
- - 750.000 EUROS - for the group of & or the framework & information for the & Annex IV - \\
$\begin{array}{l}\text { Products under the same CPV } \\
\text { (Common Procurement Vocabulary) } \\
\text { code (XXXXOOOO) }\end{array}$ & agreement is provided & European Commission & Standard Form 4: \\
-5 million EUROS for works & & & "Cyclic information \\
& & & notice-Utilities” \\
\hline
\end{tabular}


Table 2.

\begin{tabular}{|c|c|c|}
\hline Result & Awarding procedure & Applicability \\
\hline \multirow{6}{*}{$\begin{array}{l}\text { Public procurement } \\
\text { agreement }\end{array}$} & Open tendering & \multirow{2}{*}{$\begin{array}{l}\text { Does not require any condition for application } \\
\text { Represents the rule for awarding the public procurement } \\
\text { agreement }\end{array}$} \\
\hline & Restricted tendering & \\
\hline & Competitive dialog & If the respective agreement is particularly complex \\
\hline & $\begin{array}{l}\text { Negociation with publication } \\
\text { of a tender notice }\end{array}$ & $\begin{array}{l}\text { It applies only if conditions of Art. } 110 \text { of GEO } \\
\text { (Government Emergency Ordinance) no. } 34 \text { / } 2006 \text { are met }\end{array}$ \\
\hline & Call for tenders & $\begin{array}{l}\text { It applies to agreements whose estimated value does not } \\
\text { exceed } 75.000 \text { EUROS or } 500.000 \text { EUROS for works }\end{array}$ \\
\hline & $\begin{array}{l}\text { Negociation without } \\
\text { publication of a tender notice }\end{array}$ & $\begin{array}{l}\text { It applies only if conditions of Art. } 122 \text { of GEO } \\
\text { (Government Emergency Ordinance) no. } 34 \text { / } 2006 \text { are met }\end{array}$ \\
\hline \multirow{5}{*}{ Sectorial contract } & Open tendering & \multirow{3}{*}{$\begin{array}{l}\text { Does not require any condition for application } \\
\text { Represents the rule for awarding the sectorial contract, } \\
\text { Does not require an explanatory note }\end{array}$} \\
\hline & Restricted tendering & \\
\hline & $\begin{array}{l}\text { Negociation with publication } \\
\text { of a tender notice }\end{array}$ & \\
\hline & Call for tenders & $\begin{array}{l}\text { It applies to agreements whose estimated value does not } \\
\text { exceed } \\
-75.000 \text { EUROS products, services } \\
-500.000 \text { EUROS works }\end{array}$ \\
\hline & $\begin{array}{l}\text { Negociation without } \\
\text { publication of a tender notice }\end{array}$ & $\begin{array}{l}\text { It applies only if conditions of Art. } 252 \text { of GEO } \\
\text { (Government Emergency Ordinance) no. } 34 \text { / } 2006 \text { are met }\end{array}$ \\
\hline \multirow{5}{*}{$\begin{array}{l}\text { Framework } \\
\text { agreement followed } \\
\text { by subsequent } \\
\text { agreements }\end{array}$} & Open tendering & \multirow{2}{*}{$\begin{array}{l}\text { Does not require any condition for application } \\
\text { Represents the rule for awarding the sectorial contract }\end{array}$} \\
\hline & Restricted tendering & \\
\hline & $\begin{array}{l}\text { Negociation with publication } \\
\text { of a tender notice }\end{array}$ & $\begin{array}{l}\text { It applies only if conditions of Art. } 110 \text { of GEO } \\
\text { (Government Emergency Ordinance) no. } 34 \text { / } 2006 \text { are met }\end{array}$ \\
\hline & Call for tenders & $\begin{array}{l}\text { It applies for framework agreements whose cumulated } \\
\text { estimated value of the subsequent agreements does not } \\
\text { exceed: } \\
-75.000 \text { EUROS for products, services } \\
\text { - 500.000 EUROS for works }\end{array}$ \\
\hline & $\begin{array}{l}\text { Negociation without } \\
\text { publication of a tender notice }\end{array}$ & $\begin{array}{l}\text { It applies only if conditions of Art. } 122 \text { of the Ordinance are } \\
\text { met }\end{array}$ \\
\hline Solution or project & Solution bid & $\begin{array}{l}\text { It applies according to Chapter III, Section } 8 \text { from GEO no. } \\
34 \text { / } 2006\end{array}$ \\
\hline $\begin{array}{l}\text { Convenience } \\
\text { products }\end{array}$ & $\begin{array}{l}\text { Dynamic procurement } \\
\text { system }\end{array}$ & $\begin{array}{l}\text { It applies according to Chapter IV, Section } 2 \text { from GEO no. } \\
34 \text { / } 2006\end{array}$ \\
\hline $\begin{array}{l}\text { Products, works or } \\
\text { services with a } \\
\text { value, without VAT, } \\
\text { not exceeding the } \\
\text { equivalent of } 10.000 \\
\text { EUROS }\end{array}$ & Direct procurement & It applies according to Art. 19 from GEO no. 34 / 2006 \\
\hline
\end{tabular}


Table 3.

\begin{tabular}{|c|c|c|c|}
\hline $\begin{array}{l}\text { Why publish the } \\
\text { notice of tender }\end{array}$ & $\begin{array}{l}\text { When is it } \\
\text { published }\end{array}$ & Where is it published & $\begin{array}{c}\text { Content of the } \\
\text { notice }\end{array}$ \\
\hline $\begin{array}{l}\text { To initiate the } \\
\text { agreement awarding } \\
\text { procedure or the } \\
\text { conclusion procedure } \\
\text { of a framework } \\
\text { agreement by the } \\
\text { instrumentality of: } \\
\text { open tendering } \\
\text { restricted tendering } \\
\text { competitive dialog } \\
\text { negociation with } \\
\text { previous publication } \\
\text { of a tender notice } \\
\text { To start and initiate a } \\
\text { dynamic procurement } \\
\text { system (simplified } \\
\text { notice) } \\
\text { To organize a solution } \\
\text { bid }\end{array}$ & $\begin{array}{l}\text { Whenever } \\
\text { needed }\end{array}$ & $\begin{array}{l}\text { In the OJEU (Official Journal of the } \\
\text { European Union) by means of and in ESPP } \\
\text { and in The Official Gazette of Romania, Part } \\
\text { VI, Public procurements if: } \\
\text { the estimated value of the delivery / services } \\
\text { agreement } \geq 125.000 \text { EUROS } \\
\text { the estimated value of the delivery / services } \\
\text { sectorial contract } \geq 420.000 \text { EUROS } \\
\text { the estimated value of the works agreement: } \\
\text { EV } \geq 5 \text { million EUROS } \\
\text { in the ESPP and in The Official Gazette of } \\
\text { Romania, Part VI, Public procurements if: } \\
\text { the estimated value of the delivery / services } \\
\text { agreement is between } 75.000 \text { and } 125.000 \\
\text { EUROS } \\
\text { the estimated value of the delivery / services } \\
\text { sectorial contract is between } 75.000 \text { and } \\
420.000 \text { EUROS } \\
\text { the estimated value of the works agreement is } \\
\text { between } 500.000 \text { and } 5 \text { million EUROS }\end{array}$ & $\begin{array}{l}\text { Information } \\
\text { provided in the (EC) } \\
\text { Regulation No. } \\
\text { 1564/2005 for: } \\
\text { Annex II - Standard } \\
\text { Form 2: „Notice of } \\
\text { tender” } \\
\text { Annex V - Standard } \\
\text { Form 5: „Notice of } \\
\text { tender - Utilities" } \\
\text { Annex IX - } \\
\text { Standard Form 9: } \\
\text { "Simplified notice } \\
\text { of tender within a } \\
\text { dynamic } \\
\text { procurement } \\
\text { system" } \\
\text { Annex XII - } \\
\text { Standard Form 12: } \\
\text { „Notice of } \\
\text { competition” }\end{array}$ \\
\hline
\end{tabular}

Table 4.

\begin{tabular}{|l|l|l|l|}
\hline \multicolumn{1}{|c|}{ Why publish the invitation to tender } & \multicolumn{1}{|c|}{$\begin{array}{c}\text { When is it } \\
\text { published }\end{array}$} & $\begin{array}{c}\text { Where is it } \\
\text { published }\end{array}$ & $\begin{array}{c}\text { Content of the } \\
\text { notice }\end{array}$ \\
\hline $\begin{array}{l}\text { For the initiation of the awarding procedure } \\
\text { by instrumentality of call for tender }\end{array}$ & Whenever needed & Only in the ESPP & $\begin{array}{l}\text { Provisions of Art. } \\
125 \text { Par. (2) from } \\
\text { tthe Ordinance }\end{array}$ \\
\hline $\begin{array}{l}\text { To inform the financial officers in case of } \\
\text { application of the negociation without } \\
\text { publication }\end{array}$ & Whenever needed & $\begin{array}{l}\text { It is submitted to the } \\
\text { financial officers }\end{array}$ & \\
\hline
\end{tabular}

Table 5.

\begin{tabular}{|c|c|c|c|}
\hline $\begin{array}{c}\text { Why publish the notice of } \\
\text { awarding }\end{array}$ & $\begin{array}{l}\text { When is it } \\
\text { published }\end{array}$ & Where is it published & What it contains \\
\hline $\begin{array}{l}\text { To complete the awarding } \\
\text { procedure of the agreement or } \\
\text { the procedure of concluding a } \\
\text { framework agreement by means } \\
\text { of: } \\
\text { open tendering } \\
\text { restricted tendering } \\
\text { competitive dialog } \\
\text { call for tenders } \\
\text { negociation with publication of a } \\
\text { notice } \\
\text { negociation without publication } \\
\text { of a notice } \\
\text { For the completion of a solution } \\
\text { bid by establishing the winning } \\
\text { tenderer } \\
\text { For the completion of awarding } \\
\text { a public procurement agreement } \\
\text { by means of a dynamic } \\
\text { procurement system }\end{array}$ & $\begin{array}{l}\text { no later than } 48 \text { after } \\
\text { signing: } \\
\text { - the agreement } \\
\text { - the framework } \\
\text { agreement }\end{array}$ & $\begin{array}{l}\text { In the OJEU and in the ESPP if: } \\
\text { the estimated value of the delivery / } \\
\text { services agreement } \geq 125.000 \\
\text { EUROS } \\
\text { the estimated value of the delivery / } \\
\text { services sectorial contract } \geq 420.000 \\
\text { EUROS } \\
\text { the estimated value of the works } \\
\text { agreement: EV } \geq 5 \text { million EUROS } \\
\text { in the ESPP if: } \\
\text { the estimated value of the delivery / } \\
\text { services agreement is between } \\
15.000 \text { and } 125.000 \text { EUROS } \\
\text { the estimated value of the delivery / } \\
\text { services sectorial contract is } \\
\text { between } 15.000 \text { and } 420.000 \\
\text { EUROS } \\
\text { the estimated value of the works } \\
\text { agreement is between } 15.000 \text { and } 5 \\
\text { million EUROS }\end{array}$ & $\begin{array}{l}\text { Information } \\
\text { provided in the } \\
\text { (EC) Regulation } \\
\text { No. 1564/2005 } \\
\text { for: } \\
\text { Annex III - } \\
\text { Standard Form 3: } \\
\text { "Notice of the } \\
\text { awarding of the } \\
\text { agreement" } \\
\text { Annex VI - } \\
\text { Standard Form 6: } \\
\text { "Notice of the } \\
\text { awarding of the } \\
\text { agreement - } \\
\text { Utilities" } \\
\text { Annex XIII - } \\
\text { Standard Form 13: } \\
\text { "Results of the } \\
\text { solution bid" }\end{array}$ \\
\hline
\end{tabular}

